\title{
Prospects of fortification of salt with iron and iodine
}

\author{
Bhattiprolu Sivakumar*, G. N. V. Brahmam, K. Madhavan Nair, S. Ranganathan, \\ M. Vishnuvardhan Rao, K. Vijayaraghavan and Kamala Krishnaswamy \\ National Institute of Nutrition, Jamai Osmania Post, Hyderabad - 500 007, India \\ Fortification of salt with iron has been developed by the National Institute of Nutrition (NIN) as \\ a strategy for the control of iron deficiency anaemia (IDA) in India, similar to iodization of salt \\ for control of iodine deficiency disorders (IDD). Stability of the iron fortified salt (IFS), its \\ bioavailability and organoleptic evaluation of food items containing the IFS have been \\ demonstrated. Acceptability and effectiveness of the IFS in school children and in multicentric \\ community trials have been demonstrated. With the introduction of universal iodization of salt \\ as a national policy in 1988, NIN has developed a formulation for double fortification (DFS) of \\ salt with iodine and iron. The stability of the nutrients under laboratory conditions along with \\ their bioavailability were found to be good but varying with the quality of salt used. The DFS \\ has been evaluated in controlled trials in tribal communities and in residential school children. \\ The findings of these studies are discussed. Overall, in these trials, DFS effectively controlled \\ iodine deficiency but a clear impact on reducing anaemia was not demonstrated. In residential \\ schoolchildren, increased urinary excretion of iodine as well as reduced anaemia were observed. \\ The quality of salt has been found to be an important determinant of the stability of iodine in \\ DFS. Further evaluation of this potentially important intervention is in progress.
}

Iron and iodine fortified salt: Double fortified salt: Impact of haemoglobin: Urinary iodine

Iron deficiency anaemia (IDA) and iodine deficiency disorders (IDD) form major micronutrient deficiencies of public health significance in India (Seshadri, 1997; Pandav, 1997). No state in the country is believed to be free from IDD and IDA. According to 1991 estimates, the number of people exposed to the risk of IDD increased from 167 to 270 million. As compared to the prevalence of goitre of $21 \%$ in 1984 (ICMR Task Force, 1989), the current prevalence (Pandav, 1997) is $<10 \%$ indicating an overall fall in IDD as a result of the introduction of universal salt iodization programme in India.

About two thirds of children and women of child bearing age in India are estimated to be suffering from iron deficiency anaemia (Seshadri, 1997; WHO, 1998). Therapeutic dosing of iron is a short-term measure to correct IDA. Though the National Nutritional Anaemia Prophylaxis Programme, now known as the National Nutritional Anaemia Control Programme, has been in operation throughout India for many years, recent studies show that this strategy has not been effective (WHO, 1998).

As per the National Nutrition Policy (Department of Women \& Child Welfare, 1993) of Government of India reduction of goitre prevalence to less than $10 \%$ and that of IDA in pregnant women to $25 \%$ were among the goals set for the year $2000 \mathrm{AD}$. The goals are being reset to be achieved by 2010. Alternative food-based strategies such as food fortification have therefore, to be considered seriously. In developed countries, wheat flour and cerealbased foods have had significant success as vehicles for micronutrient fortification (Lotfi et al. 1996a). Fortification of milled cereals such as wheat and maize has also been adopted in several countries in Latin America and the Caribbean. Sugar has been an attractive vehicle in the Caribbean and results are encouraging in Central America for fortification with vitamin A and iron. Iodized salt has been in use for a long time in many countries including India (World Health Organization, 1997; Sooch et al. 1973). Fortification of salt with iron has been reported from India (Report of the Working Group on salt fortification with iron, 1982).

Food fortification has been a very effective strategy in controlling deficiencies of these micronutrients in developed countries. This was mainly because of the preference for processed foods in such countries and fortification involves processing of foods. Why is it then that this strategy has not been a popular national programme in developing countries such as India? One reason is that in these countries, consumption of processed foods is limited

\footnotetext{
Abbreviations: IDA, iron deficiency anaemia; IDD, iodine deficiency disorders; IS, iodized salt; IFS, iron fortified salt; DFS, double fortified salt; $\mathrm{KI}$, potassium iodide; $\mathrm{KIO}_{3}$, potassium iodate; NaFeEDTA, sodium ferric ethylene-diamine-tetracetate; PFA, Prevention of Food Adulteration Act; KAP, knowledge, attitude, practices; SHMP, stabilizer component, sodium hexametaphosphate.

* Corresponding author: Dr B. Sivakumar, fax +9140 7019074, email nin@ap.ap.nic.in
} 
to some of the urban population groups only. Secondly, selection of a suitable vehicle for food fortification is difficult due to the diversity in food preferences.

\section{Technology of food fortification in India}

The technology of food fortification mainly involves bringing together the two components, vehicle and the nutrient. With vast differences in the intakes of major cereals and pulses, no major food item can be considered a suitable vehicle for the entire population in India. Common salt, however, fits into a potentially ideal choice as it is consumed throughout the country by every socioeconomic group and throughout the year. It is an inexpensive and essential ingredient of all household food preparations. The major part of salt production is confined to two or three states in India and a well-defined distribution and monitoring machinery is in place. Technology for production of iron fortified salt (Narasinga Rao \& Vijayasarathy, 1975; Narasinga Rao \& Vijayasarathy, 1978; Nadiger et al. 1980; Report of the Working Group on Fortification of Salt with Iron, 1982) and iodine and iron fortified salt has been developed in India mainly through the efforts of National Institute of Nutrition (Narasinga Rao, 1994; Brahmam et al. 1994; Ranganathan et al. 1996; Nair et al. 1998a; Nair et al. 1998b).

\section{Iodine}

Iodine is usually used in the salt form as potassium iodide (KI) or iodate $\left(\mathrm{KIO}_{3}\right)$. Potassium iodide is a cheaper but less stable salt because of its high solubility in water and iodine is lost in extreme conditions of light, heat and humidity. Stabilizers like carbonates of calcium and magnesium are used in maintaining the stability of iodine in iodized salt (Venkatesh Mannar \& Dunn, 1995). In most cases, particularly in developing countries, $\mathrm{KIO}_{3}$ is preferred as it is less soluble and more stable than KI.

\section{Iron}

The four principal iron sources used in food fortification are elemental iron, ferrous sulphate, ferric orthophosphate and sodium ferric pyrophosphate. Sodium ferric ethylenediamine-tetracetate (NaFeEDTA) is a new iron compound, which has conditional approval for fortification (Lotfi et al. 1996b).

\section{Control of IDD and IDA through salt fortification}

\section{IDD control}

Iodization of salt is a well-tested measure of eliminating endemic goitre and other IDDs that has been adopted by many countries. The efficacy of such an intervention was evaluated for the first time in India in the pioneering Kangra Valley study during 1956-62 (Sooch et al. 1973). Production and distribution of iodized salt as a public health measure was introduced in 1962 under the National Goitre Control Programme in areas where goitre has been endemic. Unfortunately, this could not make much impact for various reasons. In 1984, considering the ramifications of IDD on human health and national productivity, the Government of India, adopted the policy to achieve universal iodization of salt by 1995 (Department of Women \& Child Welfare, 1993). The Prevention of Food Adulteration Act was amended in 1988, according to which all the edible salt should be iodized and contain at least $30 \mathrm{ppm}$ of iodine at the production level and of $15 \mathrm{ppm}$ at the consumption level. Considering a requirement of about $6 \mathrm{~kg}$ per individual per annum (including requirements for animals), about 5.6 million tonnes of salt are required and more than $60 \%$ of this is being currently produced (Pandav, 1997).

\section{Efficacy of iodized salt}

In the Kangra Valley study iodized salt was used without any stabilizer. A community study involving a tribal population of 5000 was carried out using iodized salt with calcium carbonate $(0.63 \mathrm{~g} / \mathrm{kg})$ for 2 years. The salt was found to be stable and acceptable. The goitre prevalence was significantly reduced and urinary excretion of iodine enhanced. The details of the study are described elsewhere (Brahmam et al. 1994; Nair et al. 1998a; Brahmam et al. 2000).

\section{Iron fortified salt (IFS)}

After the successful demonstration that iodized salt could be a public health programme for the control of goitre in the Kangra valley, fortification of salt with iron is considered as one of the practical approaches for the prevention and control of IDA in the population. Three decades ago, studies were initiated with common salt as a possible vehicle for iron fortification. Suitable iron compounds either with a stabilizer or an absorption promoter were identified for fortification of salt. It was demonstrated that common salt fortified with ferric orthophosphate and sodium acid sulphate or ferrous sulphate with sodium dihydrogen phosphate and sodium acid sulphate, was stable for periods upto or exceeding 9 months when stored under very humid conditions and iron bioavailability was 3-5\% (Narasinga Rao \& Vijayasarathy, 1975; Narasinga Rao \& Vijayasarathy, 1978).

\section{Impact evaluation}

The efficacy over 1-year of use of iron fortified common salt (Table 1, IFS ii) providing $1 \mathrm{mg}$ of iron per gram of salt was tested among 5-15-year-old residential school children in Hyderabad (Nadiger et al. 1980). A multicentric impact evaluation study was carried out with the same formulation in three rural (Hyderabad, New Delhi, Calcutta) and one urban area in Madras.

Representative data obtained on 5-14-year-old children of Hyderabad in different studies is shown in Fig. 1. There was significant improvement in haemoglobin status and the prevalence of anaemia was reduced after introduction of IFS in both rural and urban communities. The increment in haemoglobin in anaemics $(\mathrm{Hb}<120 \mathrm{~g} / \mathrm{L})$ was of the order of $18 \mathrm{~g} / \mathrm{L}$ and $32 \mathrm{~g} / \mathrm{L}$ respectively in boys and girls at the 
Table 1. Composition of fortified salts*

\begin{tabular}{|c|c|c|c|c|c|}
\hline \multirow[b]{2}{*}{ Ingredients } & \multicolumn{2}{|c|}{ DFS } & \multicolumn{2}{|c|}{ IFS } & \multirow[b]{2}{*}{ IS } \\
\hline & (i) & (ii) & (i) & (ii) & \\
\hline Common salt $(\mathrm{kg})$ & 1 & 1 & 1 & 1 & 1 \\
\hline $\begin{array}{l}\text { Ferrous sulfate } \\
\text { heptahydrate }(\mathrm{g})\end{array}$ & 5 & 5 & - & - & - \\
\hline $\begin{array}{l}\text { Sodiumhexameta- } \\
\text { phosphate }(\mathrm{g})\end{array}$ & 10 & 10 & - & - & - \\
\hline Ferric orthophosphate $(\mathrm{g})$ & & & 3.5 & 3.5 & \\
\hline Sodium acid sulfate $(\mathrm{g})$ & & & $5 \cdot 0$ & $5 \cdot 0$ & \\
\hline $\begin{array}{l}\text { Sodium dihydrogen } \\
\text { phosphate }(\mathrm{g})\end{array}$ & & & - & $5 \cdot 0$ & \\
\hline Calcium carbonate $(\mathrm{g})$ & - & - & - & - & 0.63 \\
\hline Potassium iodide $\mathrm{KI}(\mathrm{mg})$ & - & 52 & - & - & 52 \\
\hline \multicolumn{6}{|l|}{ Or } \\
\hline Potassium iodate $(\mathrm{mg})$ & 50 & - & - & - & 67 \\
\hline Iodine content (ppm) & 30 & 40 & - & - & $30-40$ \\
\hline Iron content (ppm) & 1000 & 1000 & 1000 & 1000 & \\
\hline
\end{tabular}

The contaminants in salt $(\mathrm{g} / 100 \mathrm{~g})$ should not be more than: moisture 1.5 magnesium 0.05 , sulfate 0.4 , calcium 0.1 , insolubles 0.15 for DFS.

* Narasinga Rao (1994), Brahmam et al. (1994) and Report of Working Group on Fortification of Salt with Iron (1982).

end of 1 year, on a diet which contributed an iron content of $35-40 \mathrm{mg} / \mathrm{d}(20-25 \mathrm{mg}$ endogenous and $15 \mathrm{mg}$ from iron fortified common salt with an absorption of $3.4 \%$ ). The prevalence of anaemia in boys was reduced to $19.4 \%$ $(n=222)$ from $51.9 \%(n=92)$ whereas in girls it was reduced to $15.5 \%(n=161)$ from $22.5 \%(n=71)$. The reduction in prevalence rates was significant at $P<0.01$ (Nadiger et al. 1980).

The results of the school study were reproduced in the multicentric study but with 3-5 times reduced increments in haemoglobin. The change in haemoglobin in experimental and control groups was $5 \cdot 3 \mathrm{~g} / \mathrm{L}$ in boys $(n=189)$ and $5.0 \mathrm{~g} / \mathrm{L}$ in girls $(n=185) ; 1.4 \mathrm{~g} / \mathrm{L}$ in boys $(n=189)$ and $-0.5 \mathrm{~g} / \mathrm{L}$ in girls $(n=105)$, respectively. Also prevalence of anaemia was reduced from 52.9 to 27 $(n=189)$ in boys and 63.8 to $33.7(n=185)$ in girls at the end of 1 year (Report of the Working Group on Fortification of Salt with Iron, 1982). Based on these results IFS was included in the regulations of Prevention of Food Adulteration Act (PFA) and found its place in midday meal programmes for school children in rural areas.

The amendment of PFA Act in 1988 stipulating that all edible salt in the country should contain statutarily prescribed amounts of iodine rendered the IFS strategy untenable. This stimulated efforts to develop a technology for double fortification of salt with iodine and iron. A formulation of salt with both iodine and iron containing sodium-hexametaphosphate as stabilizer was successfully developed (Narasinga Rao, 1994), (Table 1 DFS i and ii). This was a significant achievement since the stability of bioavailable iron is better in an acidic medium while that of iodine is better in alkaline conditions. When chemical sources of iodine and iron are bought together in common salt, iodine will be lost as vapour due to oxidation/reduction reactions.

A formulation of DFS was described by Suwanik et al. (1978) from Thailand. The salt was found to be stable with good bioavailability of iron. The results of the impact evaluation study have not been published to date. Recently, another formulation of DFS using dextrin encapsulation technology that separates chemical source of iodine from iron, has been developed at the University of Toronto. This preparation has successfully undergone laboratory tests for stability and it is reported to be undergoing evaluation for its impact (Lotfi et al. 1996b; Sattarzadeh \& Zlotkin, 1999).

\section{Stability of iodine and iron in DFS}

When stored in glass containers at room temperature and with a relative humidity of $80 \%$ in the laboratory, iodine

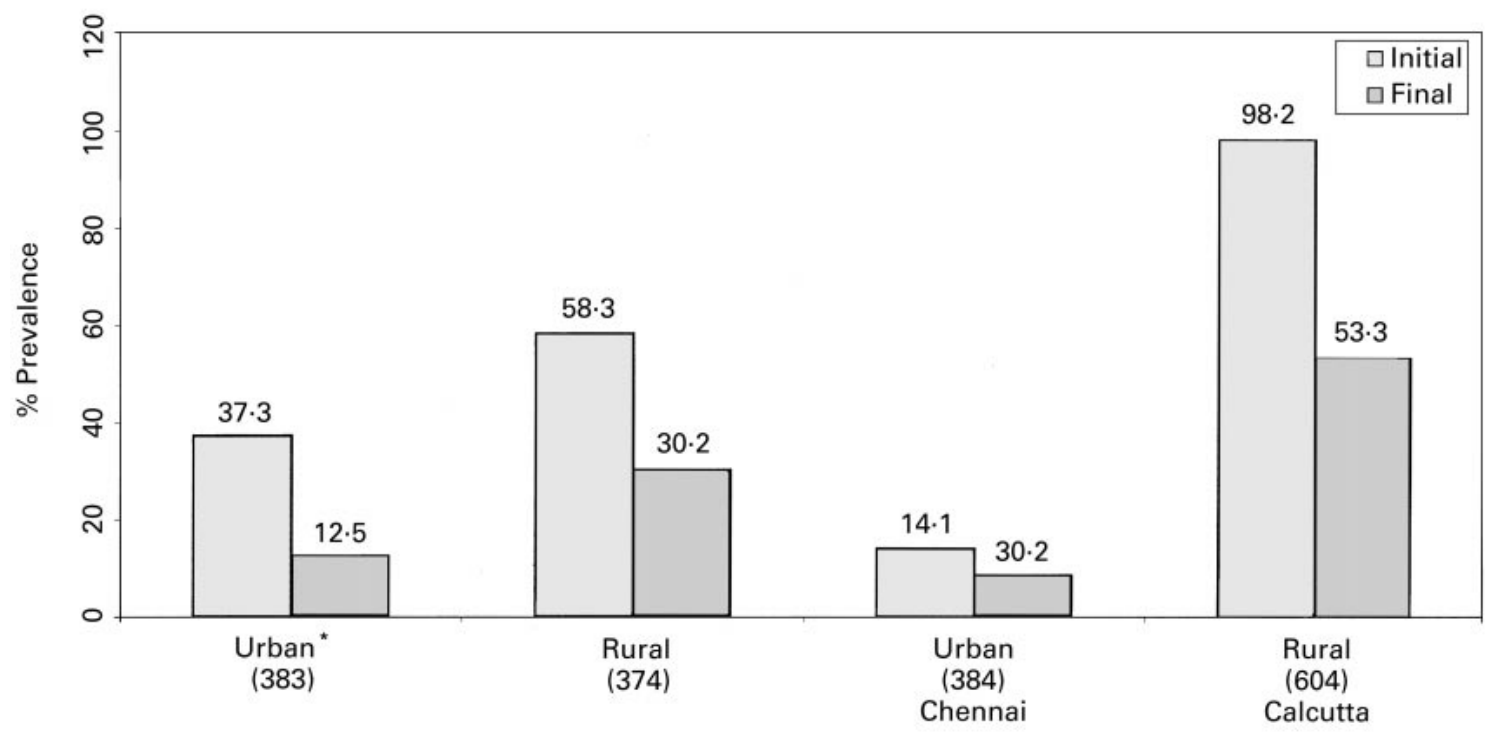

Working Group Report on Fortification of salt with iron (1982), * Nadiger et al (1980). Parenthesis indicates ' $n$ '

Fig. 1. Impact of iron fortified salt on the prevalence of anaemia in 5-14 year old children. 


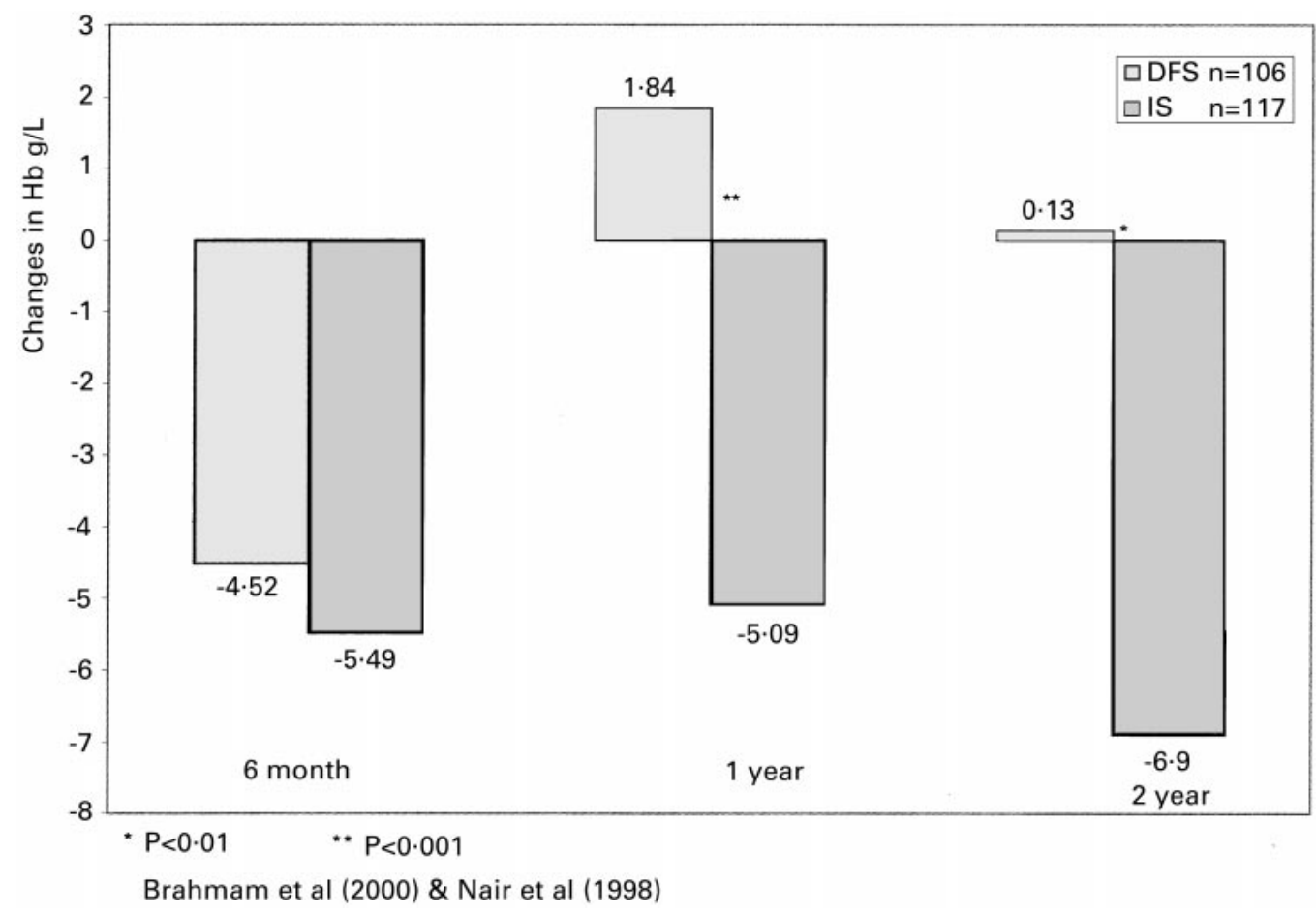

Fig. 2. Changes in haemoglobin levels of DFS and IS supplemented children with initial values of $100-120 \mathrm{~g} / \mathrm{L}$.

was stable without any loss for 6 months and marginally decreased thereafter from $30 \mathrm{ppm}$ to between $>25$ and $<30 \mathrm{ppm}$, while the iron content remained intact at 1000 ppm (Narasinga Rao, 1994).

\section{Studies in IDD endemic tribal areas}

Villages in the tribal areas of East Godavari district (Andhra Pradesh, India) endemic for goitre and with a high prevalence of IDA were chosen to assess the feasibility of large-scale production and distribution, stability, acceptability and bioeffect of DFS. Four groups of villages, twenty to twenty-five in each group, with a population of about 5000 were included in the study. Three areas received salt fortified with iron and iodine either singly or in combination. The formulations of IFS, IS and DFS used are described in Table 1. The fourth area received unfortified salt. All the areas received a regular supply of fortified salts in 1-kg packets. All these salts were produced in a local factory at Hyderabad (Brahmam et al. 1994). The study was initiated in 1989 and concluded in 1992.

Production of DFS at a factory scale was successfully demonstrated (Brahmam et al. 1994; Ranganathan et al. 1996). The stability of iodine in DFS, when tested by spot test every 3 months under the operational conditions prevailing at these tribal households, was more than 15 ppm $(n=1018)$.

The acceptability of DFS was assessed by administering KAP (knowledge, attitude, practices) schedules in the households. The tribal community readily accepted DFS as cooking salt and the compliance was $100 \%$ (Brahmam et al. 1994; Brahmam et al. 2000; Nair et al. 1998a). Undesirable effects, allergy or toxicity were not encountered.

\section{Impact on iodine status}

The prevalence of goitre decreased significantly from an initial $28 \%$ to $14 \%$ in DFS area and from $26 \%$ to $16.1 \%$ in IS area, while in the control area, there was no perceptible change $(13.5 \%$ and $14.1 \%)$. The (median) urinary iodine excretion increased from $116(n=104)$ to $155 \mu \mathrm{g} / \mathrm{L}(n=67)$ in DFS area, $59(n=89)$ to $160 \mu \mathrm{g} / \mathrm{L}$ $(n=92)$ in IS area, while it remained similar during initial (101 $\mu \mathrm{g} / \mathrm{L} ; n=102)$ and final $(97 \mu \mathrm{g} / \mathrm{L} ; n=54)$ rounds of survey in the control area.

\section{Impact on iron status - haemoglobin levels}

Overall, there was no significant impact of DFS on the prevalence of anaemia. A significant increase in haemoglobin level was observed only in certain age groups. The increments were significantly higher in lactating women in IFS area and in both 14-17-year-old boys and among lactating women in the DFS area (Table 2).

The incidence of malaria in tribal areas accounts for $40 \%$ of the total malaria cases in the country, and it was at a maximum during the course of the study (ICMR, 1994; Central Bureau of Health Intelligence, 1993). There is evidence that the improvement in haemoglobin status with iron supplements is highly variable in malarial endemic areas (INACG Consensus Statement, 1999). Consumption of substantial amounts of tamarind is reported from the tribal areas (NNMB, Report of First Repeat Survey - 
Tribal, 1999) and bioavailability of iron from a typical rice based meal was found to be reduced in the presence of tamarind (Narasinga Rao \& Prabhavati, 1982). These factors may have contributed to the marginal impact of DFS on haemoglobin.

Therefore, a study in residential school children was carried out to assess the impact of DFS on haemoglobin status in a captive group where these potential confounding factors did not operate.

\section{Studies in residential school children}

A randomized double-blind study was carried out in 1996 for a period of two years among children belonging to backward communities attending four residential schools (one each of boys' and girls' school for each salt) in and around Hyderabad (Nair et al. 1998a; Brahmam et al. 2000). For operational reasons the randomization had been at the school level and not at the individual level. DFS (Narasinga Rao, 1994) and IS were manufactured and supplied in $50 \mathrm{~kg}$ bulk packets in three and two batches, respectively, by the Tamilnadu Salt Corporation, Chennai, India.

Haemoglobin status, urinary iodine excretion and calcium-phosphorus homeostasis of the beneficiaries were evaluated. The children were followed up after 6 months, 1 year and 2 years after commencement of the study. Out of about 500 children in each school, only 107 were found to be available at the end of 2 years, mainly due to loss of the tenth class students at the end of each academic year. The actual period of total supplementation was only 18 months at the final stage, as the children passed through two seasons of vacation during the 2-year period. It may be argued that in this instance the loss of follow-up would not be a source of bias as the tenth class students were similar to the other school children and the contribution of the bias will be the same for both the treatment groups.

Compared to the baseline levels, the mean haemoglobin values showed a significant $(P<0.001)$ decline among the

Table 2. Impact of double fortified salt (DFS) and iron fortified salt (IFS) on haemoglobin in a tribal community

\begin{tabular}{|c|c|c|c|c|}
\hline \multirow[b]{2}{*}{ Group } & \multicolumn{2}{|c|}{$14-17 y$} & \multirow{2}{*}{$\begin{array}{l}\text { Lactating } \\
\text { women }\end{array}$} & \multirow{2}{*}{$\begin{array}{l}\text { Pregnant } \\
\text { women }\end{array}$} \\
\hline & Male & Female & & \\
\hline \multicolumn{5}{|l|}{ Control } \\
\hline Initial & $\begin{array}{c}124^{a} \pm 23 \cdot 6 \\
(22)\end{array}$ & $\begin{array}{c}113^{a} \pm 13 \cdot 8 \\
(24)\end{array}$ & $\begin{array}{c}107^{a} \pm 12 \cdot 6 \\
(32)\end{array}$ & $\begin{array}{c}91^{a} \pm 14 \cdot 7 \\
(14)\end{array}$ \\
\hline $\begin{array}{l}\text { At the end } \\
\text { of } 2 y\end{array}$ & $\begin{array}{c}126^{a} \pm 22 \cdot 9 \\
(8)\end{array}$ & $\begin{array}{c}120^{a} \pm 19 \cdot 3 \\
(24)\end{array}$ & $\begin{array}{c}109^{a} \pm 21.5 \\
(26)\end{array}$ & $\begin{array}{c}99^{a} \pm 17 \cdot 3 \\
(14)\end{array}$ \\
\hline \multicolumn{5}{|l|}{ IFS } \\
\hline Initial & $\begin{array}{c}118^{a} \pm 14.5 \\
(19)\end{array}$ & $\begin{array}{c}107^{a} \pm 13 \cdot 0 \\
(32)\end{array}$ & $\begin{array}{c}104^{a} \pm 14.8 \\
(68)\end{array}$ & $\begin{array}{c}99^{a} \pm 11 \cdot 2 \\
(30)\end{array}$ \\
\hline $\begin{array}{l}\text { At the end } \\
\text { of } 2 y\end{array}$ & $\begin{array}{c}132^{a} \pm 22 \cdot 0 \\
(9)\end{array}$ & $\begin{array}{c}113^{\mathrm{a}} \pm 15 \cdot 7 \\
(30)\end{array}$ & $\begin{array}{c}113^{\mathrm{b}} \pm 21 \cdot 8 \\
(43)\end{array}$ & $\begin{array}{c}105^{a} \pm 15 \cdot 2 \\
(14)\end{array}$ \\
\hline \multicolumn{5}{|l|}{ DFS } \\
\hline Initial & $\begin{array}{c}122^{\mathrm{a}} \pm 20 \cdot 7 \\
(18)\end{array}$ & $\begin{array}{c}111^{\mathrm{a}} \pm 10.5 \\
(15)\end{array}$ & $\begin{array}{c}104^{\mathrm{a}} \pm 20 \cdot 7 \\
(47)\end{array}$ & $\begin{array}{c}96^{a} \pm 16 \cdot 7 \\
(15)\end{array}$ \\
\hline $\begin{array}{l}\text { At the end } \\
\text { of } 2 y\end{array}$ & $\begin{array}{c}137^{b} \pm 17.9 \\
(18)\end{array}$ & $\begin{array}{c}114^{a} \pm 22 \cdot 0 \\
(19)\end{array}$ & $\begin{array}{c}114^{\mathrm{b}} \pm 11 \cdot 6 \\
(35)\end{array}$ & $\begin{array}{c}104^{\mathrm{a}} \pm 16 \cdot 2 \\
(25)\end{array}$ \\
\hline
\end{tabular}

Values are mean $\pm s d$. Values in parenthesis indicate the sample size. The means with different superscript letter in a group are significantly different at $P<0.05$ by Student's $t$-test.
DFS and IS groups at the end of 2 years (Table 3$)$. Notably, the decline was less in the DFS group $(-4 \cdot 2 \mathrm{~g} / \mathrm{L})$ compared to IS group $(-11.3 \mathrm{~g} / \mathrm{L} ; P<0.001)$. The generalized decrease in haemoglobin levels in both the groups may be due to the increased physiological requirement for iron during the growth phase and the additional amount of iron supplemented through DFS (about 8-10 mg per day), was perhaps not adequate to increase the mean levels overall of $\mathrm{Hb}$. However, when only children with mild anaemia (100-120 g/L Hb) were considered, significantly greater increments of haemoglobin were noted in those receiving DFS $(6.8 \mathrm{~g} / \mathrm{L})$ both at the end of 1 year and 2 years.

The increments in haemoglobin at 2 years showed a negative correlation with initial haemoglobin level in the children. When the increments in haemoglobin levels between the IS and DFS groups were adjusted for the effects of age, sex and initial haemoglobin by ANOVA, there was a significant difference $(P<0.001)$ between the adjusted means, indicating an overall improvement of iron status in DFS group.

When all the school children in both the treatment groups were categorized as (I) those who showed no change $(< \pm 10 \mathrm{~g} / \mathrm{L})$, (ii) those who improved $(\geq+10 \mathrm{~g} / \mathrm{L})$ and (iii) those who deteriorated $(\geq-10 \mathrm{~g} / \mathrm{L})$, there was a significant association between the desirable shift in haemoglobin and consumption of DFS $(P<0.01)$. It was concluded that DFS improved the haemoglobin levels of anaemic children and was able to reduce the prevalence of anaemia (Brahmam et al. 2000).

\section{Impact on urinary iodine excretion}

The median urinary levels of iodine $(\mu \mathrm{g} / \mathrm{L})$ increased significantly $(P<0.05)$ from 76 to 176 and 35 to 79 , respectively in boys and girls in DFS fed groups, while those in IS fed groups increased from 73 to 522 in boys and 65 to 414 in girls, respectively. The urinary iodine content roughly varied according to the iodine content of the salts collected from schools during the same time (Table 4). These results clearly demonstrate the beneficial impact of DFS in increasing urinary excretion of iodine.

\section{Safety of stabilizer component sodium hexametaphosphate (SHMP) in DFS}

Though SHMP is an approved food additive, doubts have often been raised about the safety of DFS, as it would form

Table 3. Changes in haemoglobin at the end of 2 years in school children receiving iodized salt (IS) and double fortified salt (DFS)

\begin{tabular}{lccc}
\hline \multirow{2}{*}{ Group } & \multicolumn{3}{c}{ Haemoglobin $(\mathrm{g} / \mathrm{L})$} \\
\cline { 2 - 4 } & Initial & At the end of $2 \mathrm{y}$ & Change \\
\hline IS $(n=352)$ & $118 \cdot 7^{\mathrm{a}} \pm 16 \cdot 1$ & $107 \cdot 4^{\mathrm{b}} \pm 20 \cdot 7$ & $-11 \cdot 3 \pm 19 \cdot 4$ \\
153 boys +199 girls & & & \\
DFS $(n=448)$ & $122 \cdot 3^{\mathrm{b}} \pm 15 \cdot 5$ & $118 \cdot 0^{\mathrm{a}} \pm 19 \cdot 8$ & $-4 \cdot 2^{\star} \pm 17 \cdot 7$ \\
187 boys +261 girls & & & \\
\hline
\end{tabular}

Values are mean $\pm \mathrm{sd}$. The means with different superscript in both rows and columns are significantly different, $P<0.001$ by $t$-test. ${ }^{\star} P<0.01$ as compared to IS group. 
Table 4. Effect of double fortified salts (DFS) and iron fortified salts (IFS) on urinary iodine excretion $(\mu \mathrm{g} / \mathrm{L})$ in residential school children

\begin{tabular}{|c|c|c|c|c|c|}
\hline \multirow[b]{2}{*}{ Time } & \multirow{2}{*}{$\begin{array}{l}\text { Urinary } \\
\text { iodine }\end{array}$} & \multicolumn{2}{|c|}{ Boy } & \multicolumn{2}{|c|}{ Girl } \\
\hline & & DFS & IS & DFS & IS \\
\hline \multicolumn{6}{|l|}{ Basal } \\
\hline & $\begin{array}{l}\text { Median } \\
\quad(\mu \mathrm{g} / \mathrm{L})\end{array}$ & 76 & 73 & 35 & 65 \\
\hline & $\begin{array}{l}\text { Range } \\
n\end{array}$ & $\begin{array}{l}38-249 \\
47\end{array}$ & $\begin{array}{l}15-252 \\
44\end{array}$ & $\begin{array}{l}9-354 \\
44\end{array}$ & $\begin{array}{l}17-275 \\
43\end{array}$ \\
\hline \multicolumn{6}{|l|}{1 year } \\
\hline & $\begin{array}{l}\text { Median } \\
\quad(\mu \mathrm{g} / \mathrm{L})\end{array}$ & 395 & 565 & 195 & 615 \\
\hline & $\begin{array}{l}\text { Range } \\
n\end{array}$ & $\begin{array}{l}46-800 \\
68\end{array}$ & $\begin{array}{l}61-1262 \\
45\end{array}$ & $\begin{array}{l}78-640 \\
45\end{array}$ & $\begin{array}{l}211-1273 \\
48\end{array}$ \\
\hline \multicolumn{6}{|l|}{2 years } \\
\hline & $\begin{array}{l}\text { Median } \\
(\mu \mathrm{g} / \mathrm{L})\end{array}$ & 176 & 522 & 79 & 414 \\
\hline & $\begin{array}{l}\text { Range } \\
n\end{array}$ & $\begin{array}{l}38-249 \\
38\end{array}$ & $\begin{array}{l}116-1081 \\
37\end{array}$ & $\begin{array}{l}33-218 \\
39\end{array}$ & $\begin{array}{l}125-928 \\
38\end{array}$ \\
\hline
\end{tabular}

The urinary iodine at 1 and 2 years corresponds to the iodine content of salt in batches 2 and 3 (Table 5).

part of the food consumed daily and that SHMP as polyphosphate could alter calcium and phosphorus balance. Tests on long-term consumption of DFS containing SHMP as a part of the daily food were initially performed in rats (Nair et al. 1998b). Apart from improving the haemoglobin status of iron deficient rats, consumption of DFS over 10 months did not alter the calcium and phosphorus balance as reflected by plasma levels or 24-hour urinary excretion. Only a significant increase in serum phosphorus without any changes in whole body X-ray radiography and histology of important organs including parathyroid, kidney, intestine and bone, indicated the safety of SHMP and DFS in rats.

\section{Safety of double fortified salts in children}

There have been no undesirable features associated with the use of IS and DFS in school children. This was also the case in the tribal population study. No change was noted in serum calcium, phosphorus and alkaline phosphatase, after 18 months of consumption of DFS in children (Nair et al. 2000). The urinary levels of calcium and phosphorus in DFS fed children were also not different from those of IS children indicating that consumption of DFS containing a polyphosphate stabilizer for 2 years did not alter calcium and phosphorus homeostasis.

\section{Iodine stability in double fortified salts and quality of salt}

The iodine content of double fortified salts collected from the residential schools during the study period varied from 1 to $48 \mathrm{ppm}$ whereas in IS it varied from 8 to $56 \mathrm{ppm}$ (Table 4). The urinary excretion data in children was consistent with the iodine content of the salts. The iodine content of DFS in the first and the third batch was below acceptable limits $(<15 \mathrm{ppm})$. There are two obvious reasons for the loss of iodine in DFS. Analysis of the quality of salt used for DFS production revealed that the defined quality of salt was not used (Tables 1 and 5). The salt supplier did not maintain good quality control at the production level and the magnesium and insoluble solid content particularly exceeded prescribed limits. The other reason could be the bulk packing of the fortified salt supplied for the school (50$\mathrm{kg}$ packets) as against 1-kg packets of iodine in the tribal area study.

The stringent standards of the salt needed for the success of double fortification highlight the limitations of the present technology as only limited amounts of such salt in large quantities are readily available. Development of alternative technology for fortification of the iodized salt with iron needs to be explored.

\section{Conclusions}

Common salt has been shown to be a good vehicle for fortification with nutrients like iodine or/and and iron. However, addition of a stabilizer like SHMP or encapsulation of one of the nutrients was found necessary to maintain acceptable colour and stability of iodine in the double fortified salt. The large-scale production and supply of DFS were found feasible. The use of IFS as a cooking salt by the community reduced the prevalence of anaemia and increased their haemoglobin, but that of DFS had striking impact on iodine status. The response of DFS on haemoglobin status was not uniform in all the population groups studied in a tribal community. The study on residential school children, however, showed that DFS could prevent deterioration of haemoglobin level and reduce the prevalence of anaemia. Further improvements in technology to stabilize iodine or adherence to stringent quality requirements and packaging of the salt are necessary for DFS to become available as a long-term strategy for the control of iodine and iron deficiency.

Table 5. Quality of salt used for double fortified salts (DFS) and iodized salts (IS) production for the residential school study

\begin{tabular}{|c|c|c|c|c|c|c|c|c|}
\hline \multirow[b]{2}{*}{ Batch } & \multicolumn{2}{|c|}{ lodine* $\left.^{*} \mathrm{ppm}\right)$} & \multicolumn{2}{|c|}{ Moisture* $\left.^{*} \mathrm{~g} / 100 \mathrm{~g}\right)$} & \multicolumn{2}{|c|}{ Magnesium $(\mathrm{g} / 100 \mathrm{~g})$} & \multicolumn{2}{|c|}{ Insolubles ( $\mathrm{g} / 100 \mathrm{~g})$} \\
\hline & DFS & IS & DFS & IS & DFS & IS & DFS & IS \\
\hline Batch 1 & $7 \cdot 0$ & 27 & 0.2 & 0.1 & 1.2 & 0.04 & 0.65 & 0.23 \\
\hline Batch 2 & $15 \cdot 0$ & 34 & 0.2 & 0.1 & 0.96 & 0.04 & 0.20 & 0.23 \\
\hline Batch 3 & 3.4 & 31.5 & 0.4 & 0.4 & 1.07 & 0.07 & 0.70 & 0.36 \\
\hline
\end{tabular}

* Refer to Table 4 footnote for the correspondence of iodine content of salt and urine. DFS batch 3 contained only 713 ppm iron compared to 1000 ppm in other batches of salt 


\section{References}

Brahmam GNV, Madhavan Nair K, Ranganathan S, Gal Reddy Ch, Vishnuvardhan Rao M, Nadamuni Naidu A, Pralhad Rao \& Vinodini Reddy (1994) Use of common salt fortified with iron and iodine (double fortified salt) - a community study in Andhra Pradesh. National Institute of Nutrition, ICMR, Hyderabad.

Brahmam GNV, Nair, MK, Laxmaiah A, Gal Reddy Ch, Ranganathan S, Vishnuvardhana Rao M, Nadamuni Naidu A, Vijayaraghavan K, Sivakumar B, Krishnaswamy K, Gowrinath Sastry J, Mohanram M, Pralhad Rao N \& Reddy V (2000) Community trials with iron and iodine fortified salt (double fortified salt). Proceedings of the 8th World Salt Symposium, 6-8 May 2000, The Hague, The Netherlands, pp. 955-960.

Central Bureau of Health Intelligence (1993) Directorate-General of Health Services, Ministry of Health and Family Welfare, Government of India, Nirman Bhavan, New Delhi. Health Information in India.

Department of Women \& Child Welfare (1993) Ministry of Human Resource Development, Government of India, New Delhi. A National Nutrition Policy.

ICMR Task Force study (1989) Epidemiological survey of endemic goitre and endemic cretinism, pp. 10-39. ICMR, New Delhi.

ICMR (1994) Annual Report of Director-General 1993-94, pp. 26. Indian Council of Medical Research, New Delhi.

INACG Consensus Statement (1999) Safety of iron supplementation programs in malaria - endemic regions. Washington, DC: INACG Secretariat, ILSI.

Lotfi M, Venkatesh Mannar MG, Merx RJHM \& den Hauvel (1996a) Review of research and current practices in micronutrient fortification. In Micronutrient Fortification of Foods - Current Practices, Research and Opportunities, Chapter 7, pp. 39-79. Ottawa, Canada: Micronutrient Initiative (IDRC).

Lotfi M, Venkatesh Mannar MG, Merx RJHM \& den Hauvel PN (1996b) Food vehicles and fortificants. In Micronutrient Fortification of Foods - Current Practices, Research and Opportunities, Chapter 3, pp. 11-24. Ottawa, Canada: Micronutrient Initiative (IDRC).

Nadiger HA, Krishnamachari KAVR, Nadamuni Naidu A, Narasinga Rao BS \& Srikantia SG (1980) The use of common salt (sodium chloride) fortified with iron to control anaemia results of a preliminary study. British Journal of Nutrition $\mathbf{4 3}$, $45-51$.

Nair KM, Brahmam GNV, Ranganathan S, Vijayaraghavan K, Sivakumar B \& Kamala Krishnaswamy (1998a) Impact evaluation of iron and iodine fortified salt. Indian Journal of Medical Research 108, 203-211.

Nair KM, Sesikaran B, Ranganathan S \& Sivakumar B (1998b) Bioeffect and safety of long term feeding of common salt fortified with iron and iodine (double fortified salt) in rat Nutrition Research 18, 121-129.

Nair KM, Brahmam GNV, Lakshmaiah A, Gal Reddy Ch, Vishnuvardhan Rao M, Ranganathan S, Vijayaraghavan K, Sivakumar B, Kamala Krishnaswamy (2000) Sodium hexametaphosphate (SHMP) as a stabilizer of double fortified (iron and iodine) salt does not alter the calcium and phosphorus homeostasis. Proceedings of the 8th World Salt Symposium. 6-11 May 2000, pp. 1253-1254. The Hague, The Netherlands.

Narasinga Rao BS (1994) Fortification of salt with iron and iodine to control anaemia and goitre. Development of a new formula with good stability and bioavailability of iron and iodine. Food and Nutrition Bulletin 15, 32-39.

Narasinga Rao BS \& Prabhavathi T (1982) Tannin content of foods commonly consumed in India and its influence on ionisable iron. Journal of Science Food and Agriculture 33, 89-96.

Narasinga Rao BS \& Vijayasarathy C (1975) Fortification of common salt with iron: effect of chemical additives on stability and bioavailability. American Journal of Clinical Nutrition 28, 1395-1401.

Narasinga Rao BS \& Vijayasarathy C (1978) An alternate formula for the fortification of common salt with iron. American Journal of Clinical Nutrition 31, 1112-1114.

Pandav C (1997) Sustaining elimination of iodine deficiency disorders in South Asia. In Malnutrition in South Asia - A Regional Profile [S Gillespie, editor]. Khatmandu, Nepal: UNICEF Regional Office for South Asia, Rosa Publication No. 5.

Ranganathan S, Reddy V \& Ramamoorthy P (1996) Large scale production of salt fortified with iodine and iron. Food and Nutrition Bulletin 17, 73-78.

Report of the Working Group on Fortification of Salt with Iron (1982) Use of common salt fortified with iron in the control and prevention of anaemia - a collaborative study. American Journal of Clinical Nutrition 35, 1442-1451.

Sattarzadeh M \& Zlotkin SH (1999) Iron is well absorbed by healthy adults after ingestion of double fortified (iron and dextran-coated iodine) table salt and urinary iodine excretion is unaffected. Journal of Nutrition 129, 117-121.

Seshadri S (1997) Nutritional anaemia in South Asia. In Malnutrition in South Asia. A Regional Profile, pp. 145-159 [S Gillespie, editor]. Khatmandu, Nepal: UNICEF Regional Office for South Asia, Rosa Publication No. 5.

Sooch SS, Deo MG, Karmarkar MG, Kochupillai N, Ramachandran K \& Ramalingaswamy V (1973) Prevention of endemic goitre with iodised salt. Bulletin of World Health Organization 49, 307-312.

Suwanik R and the Study Group; Bangkok (1978) Iron and iodine fortification in Thailand. Bangkok: Faculty of Medicine, Siriraj Hospital, Mahidol University.

Venkatesh Mannar MG \& Dunn JT (1995) In Salt Iodization for the Elimination of Iodine Deficiency. The Netherlands: ICCIDD.

World Health Organization (1997) Elimination of iodine deficiency disorders in South-East Asia. A report of the Regional Consultation, SEA/NUT/ 138. New Delhi.

World Health Organization (1998) Nutritional status of adolescent girls and women of reproductive age. A report of the Regional conference. New Delhi: WHO, SEARO. 